\title{
腰椎，膝関節疾患と誤られた総腓骨神経圧迫症候群症例について
}

\author{
福岡大学筑紫病院整形外科 \\ 江島 光 史 - 松 崎昭 夫 \\ 塩田悦仁・有永誠
}

\section{Cases of the Entrapment Neuropathy of the Common Peroneal Nerve Misdiagnosed as the Lumbar and Knee Disorders}

\author{
Akifumi Eshima, Akio Matsuzaki, Etsuji Shiota, and Makoto Arinaga \\ Department of Orthopaedic Surgery, Chikushi Hospital, Fukuoka University
}

\begin{abstract}
41 limbs in 34 patients with entrapment neuropathy of the common peroneal nerve were operated on in our department. Among these, 11 limbs in 7 cases were diagnosed as having osteoarthritis, and 11 limbs in 11 case as lumbar disc herniation before our diagnosis.

The causes of these misdiagnoses were investigated with medical care records.

The causes of misdiagnoses as lumbar disc herniations were as follows : paresthesia from the lateral aspect of the leg to the dorsal aspect of the foot as the patient complaint, misunderstanding of the symptoms from the extension and compression of the common peroneal nerve as a positive SLRT (straight leg raising test), relying on image studies without precise examination of the physical findings, and no consideration of the entrapment neuropathy as a differential diagnosis.

The causes of misdiagnoses as knee joint disorders were as follows : gonalgia as the patient complaint, diagnosis relying on image studies without precise examination of the physical findings, and no consideration of the entrapment neuropathy as a differential diagnosis.

In the diagnosis of lumbar spinal and knee joint disorders, the entrapment neuropathy of the common peroneal nerve should be considered as a differential diagnosis.
\end{abstract}

Key words : common peroneal nerve (総腓骨神経), entrapment neuropathy（絞扼性神経障害), surgery/ operative method (手術療法)

はじめに

日常診療で腰部疾患・膝関節疾患診療時に総腓骨神 経圧迫症候群を鑑別に挙げることの必要性については 既に報告している3゙.しかし一般には本症に対する整 形外科医の認識は薄く, 誤って診断・治療をされてい る症例をしばしばみる，本症に対する注意を喚起する ために我々の手術例中上記二疾患と誤って診断・治療 されていた症例を検討して報告する.
対

象

1985 年 7 月当院開設以来 1998 年末までに観血的に 治療した総腓骨神経圧迫症候群の患者 34 例 41 肢を対 象とし，その病歴を調查した。内訳は男性 15 例女性 19 例，平均年齢は 55.6 歳（26-86 歳）であった.

調 查結 果

34 例中総腓骨神経圧迫症候群と診断される前に腰 部疾患または膝関節疾患と診断又は治療されていた症 
例は 18 例 22 肢（男性 7 例，女性 11 例）でその内訳 は以下の通りであった。

腰部疾患とされていたもの：11 症例 11 肢で男 4 例, 女 7 例, 右 6 肢, 左 5 肢であった。症例の平均年齢は 56.9 歳（35-78 歳）であった。主訴は重なりがある が腰痛 5 例, 下腿外倒から足背にかけてのしびれ又は 痛み 7 例，足の動きが悪い，つまずき易い 2 例，足背 の痛み 1 例であった。診断は椎間板へルニア 5 例, 腰 部脊椎管狭窄症 3 例, 变形性脊椎症 1 例, 腰痛症 1 例, 左下肢閉塞性動脈硬化症 1 例などがつけられていた. 既に椎間板へルニアとして手術されたが症状の改善を 認めなかったもの 2 例, 椎間板へルニアの手術を勧め られていたがその症状を認めなかったもの 2 例, 椎間 板へルニアと診断され，その所見を認めたあの1例で, 腰痛症を治療対象とされていたものが 2 例であった. 症例中 10 例で硬膜外ブロックが行われていたがいず れも麻酔効果持続期間中のみの症状改善で, 治療効果 を認めていなかった。腰部の所見が認められたものは 6 例あった. SLRT が陽性と記載されていたものが 3 例あったが, うち 1 例は前記根性坐骨神経症状を認 めた例であり, 残り 2 例は総腓骨神経の伸展・圧迫に よる痛みであった．椎間板へルニアと診断されたもの の 4 例が MRI の検査所見を基に診断されており，根 性坐骨神経痛を認めた 1 例は術前検查として春䯙造影・ $\mathrm{CT}$ 検査が行われていた.

膝関節疾患とされたもの：7 症例 11 肢で男 3 例, 女 4 例, 右 1 肢, 左 2 肢, 両側 4 例であった．症例の 平均年齢は 52.9 歳 $(24-71$ 歳) で 24 歳の例は中学生 時に半月の切除をされ，ずっとバレーボールを続けて いた例である. 主訴が膝痛であったものは 7 例で，う ち 1 例は歩行時の膝痛, 残り 1 例はあぐらをかいたと きの下腿のビリビリ感であったが前医の半月障害の診 断で入院していた．变形性膝関節症の診断で治療され ていたものが 6 例 9 肢（男性 2 例，女性 4 例）で, 右 1 肢, 左 2 肢, 両側 3 例であった。残る 1 例は 24 歳 の症例で半月障害の診断で関節鏡検查が予定されてい た. 来院前に受けていた治療は関節内注射, 理学療法, 薬物療法であったがいずれも期待した結果が得られて いなかった． 3 例は人工関節置換術を勧められており， うち 1 例は痛みが強いので一日も早く手術してもらい たいと受診したものであった.

患者が訴えた症状 : 主訴は重なりがあるが下腿外側 より足背にかけてのしびれ，痛み,じんじん感などを
訴えたもの 12 例, 膝痛, 滕後外側痛を訴えたもの 8 例, 足関節の背屆障害 1 例であった。主訴ではないが 関係した訴えとして膝を伸ばすと痛みが増し，下腿が しびれると訴えたものが 3 例があった. 併発症状とし て腰痛がみられた症例もあった。

総腓骨神経に関する所見 : 総腓骨神経支配域の知覚 鈍麻が 21 例全てで認められたが, その範囲は腓骨頸 部直下よりのむの 15 肢, 下腿中央以下 5 肢, 浅枝領 域 1 肢, 深枝領域 1 肢であった. 神経走行に沿った圧 痛は大腿二頭筋出口, 大腿骨外側顆上, 脛骨顆上, 腓 骨頭部，腓骨頸部後外側，同外側などであった。

運動麻痹症状としての筋力低下は長母趾伸筋筋力低 下が 8 肢でみられた.

運動神経伝導速度の測定は患者説明と経過観察のた めに行っている. 17 例で測定しているが 10 例で遅延 が認められた。

その他同側肢に同時に認められた絞扼性神経障害と して足根管症候群 4 例, 伏在神経膝蓋下枝絞拒性障害 2 例, 前足根管症候群 1 例, 浅腓骨神経 1 例があった.

圧迫部位 : 手術時に確かめた圧迫部位は重複がある が大腿二頭筋下出口 4 肢, 大腿骨外側顆後方 （Fabellaによるむのを含む）13肢, 脛骨顆後方 5 肢, 腓骨頭のすぐ近位で神経を横切る膜様組織 4 肢, 腓骨 頭後方 5 肢, 長腓骨筋入り口 4 肢, 腓骨䅡部外側 5 肢 であった。

追跡結果 : 術後平均 2 年 8 月での結果は全例経過良 好であった.

\section{考察}

はっきりした運動麻瘒を呈する総腓骨神経総麻疸を 見逃す整形外科医はないが, 痛みまたは自発性異常感 覚を呈するものは日常の診療では殆どが見逃されてい ると思われる ${ }^{3)}$. 総腓骨神経圧迫症候群は注意してみ ていると外来でよくある疾患で, 一般には保存的に治 療され手術であよく治癒する疾患である(1)274)577.

しかし，その訴えより腰部疾患・膝関節疾患とよく 間違われるためにこれら疾患を診る時は常に鑑別に挙 げるべき疾患である ${ }^{3)}$.

このような誤りの例につき症状のはっきりした手術 症例で検討した，本症は単独で起こるだけでなく，根 性坐骨神経痛や膝関節疾患之同時に見られること ${ }^{1)}$ それら疾患の治療中に併発したり, 又梨状筋症候群と 重なることもあり, 治療中の疾患増悪と間違われるこ 
とがある，従って初診時のみでなく，これら疾患治療 中に症状の変化があった場合は必ずチェックする必要 がある.

これら他疾患の合併の場合は診断に注意を要する。 ほかに multiple crush ${ }^{6)}$ の場合は各絞扼点での症状 がどの程度患者が訴える症状に関与しているかの判断 も重要になる。

本症候群で一番多い訴えは下腿外側から足背のしび れ感，または痛みである。この訴えを聞けば整形外科 医の多くは反射的に根性坐骨神経痛を考えることであ ろう．身体所見をよく診ず，MRI 検查すれば患者の 年龄からして椎間板の膨隆を見ることは稀でなく、す ぐにそれと結びつける結果になる。本症と根性坐骨神 経痛が同時に見られるときはなおさらで本症の存在ま で考えられることはまずないであろう，症例によって は膝関節の伸展で総腓骨神経の圧迫が増して痛みの増 強を訴える.このような症例ではSLRT が陽性と誤 られることになる. 以上のようなことが誤りの原因で ある. 更に問題なのは患者診察時に本疾患が鑑別に挙 がらないことであろう。もし鑑別に挙げれば, 病歴, 症状の経過であ見当がつくし, 神経の圧痛, ブロック の利用で診断は容易である. 神経ブロックは薄い局麻 剤少量ですべきで, 量が多いと検查後の帰りに運動麻 痺を起こすことがあるので患者には十分注意を与えて おかねばならない，この鑑別法は同時に根性坐骨神経 痛があった場合両者の症状への関与の割合の判別にも 利用できる. 圧痛は圧迫部位に認められるが時に圧痛 がわかりにくいこともあるので慎重に調べる必要があ る. 身体所見で腰椎の可動性は腰椎疾患の合併がなけ れば良好であるし，反射異常もない．

膝関節疾患についても同様で病歴をよく聞くことで ある. 膝の痛みといってもよく聞くと本症では後外側 または後方と訴えることが殆どである. 又軽症では症 状に波がある. 膝痛と聞いただけで, X線写真だけで 判断すると, 患者の多くが中・高年であり, 容易に変 形性関節症之誤られる. 痛みの性質も变形性関節症や
関節炎とは違うし診察すれば知覚障害と圧痛の有無で 容易に区別できる．鑑別に挙げられないことが間違い の大きな原因であると考える．この場合も当然変形性 関節症や関節炎, 伏在神経絞扼性障害などと同時に見 られることがあるし, 調べた症例の中には変形性関節 症として治療中に起こってきたのに気づかずそのまま の治療を続けられて少しも変わらないと訴えて来院し た患者もあった。

本症を鑑別に挙げず, 簡単な診察むなされないこと で無駄な治療がされていたわけである.

\section{結語}

当科で治療した総腓骨神経絞扼性神経障害の症例中 腰部疾患・膝関節疾患と誤られていた例の検討をおこ なった。

診断が誤られた原因を検討しこれら疾患診療時に は本症候群を鑑別に拳げることの重要性につき述べた.

\section{参 考 文 献}

1) Fabre. T, Piton. C, Andre. D, Lasseur. E, Durandeau A. Peroneal Nerve Entrapment. J Bone and Joint Surg $1998 ; 80-$ A : 47-53.

2) Leach RE, Purnell MB, Saito A. Peroneal nerve entrapment in runners. Am J Sports Med $1989 ; 17: 287$ 91.

3）松崎昭夫, 太田圭介, 城戸正喜, 足立 裕 : 膝後方で の総腓骨神経圧迫性障害, 日本整形外科学会誌. 1991 ; $65: 340$.

4) Matuzaki A. Das Kompressionssyndrom des Nervus peronaeus communis. Operative Orthopadie und Traumatologie. $1996 ; 8: 73-9$.

5) Sandhu HS, Sandhey BS. Occupational compression of the common peroneal nerve at the neck of the fibula. Aust NZ J Surg $1976 ; 46: 160-3$.

6) Upton AR, McComas AJ. The double crush in nerve entrapment syndromes. Lancet $1973 ; 2: 359-62$.

7) Vastamäki M. Decompression for peroneal nerve entrapment. Acta Orthop Scand. 1986 ; 57 : 551-4. 